\title{
Cognitive Empathy and Leadership Performance of Middle Level Educational Managers in a State University
}

\author{
Riomar Obliopas*, ${ }^{*}$, Felix Afable ${ }^{2}$ and Janette Rivera ${ }^{3}$ \\ ${ }^{1}$ Assistant Director, Research and Development Services* \\ 2Dean, Graduate School \\ ${ }^{3}$ Assistant Professor, College of Arts and Sciences Eastern Samar State University, \\ Philippines
}

\section{Article Type: Article \\ Article Citation: Riomar Obliopas, Felix Afable, Janette Rivera. Cognitive empathy and leadership performance of middle level educational managers in a state university. Indian Journal of Science and Technology. 2020; 13(05), 576-586. Dol: 10.17485/ijst/2020/ v013i05/149372}

Received date: December 3, 2019

Accepted date: January 5, 2020

*Author for correspondence: Riomar 0bliopas \riomaroblioas@ gmail.com $९$ Eastern Samar State University, Philippines

\begin{abstract}
Objective: This study aimed at evaluating the relationship between cognitive empathy and leadership performance of the middle level educational managers in a Philippine State University. Methodology: Utilizing the correlation method of research, data collected via the administration of two sets of questionnaires to 59 respondents across campuses were analyzed using appropriate descriptive and inferential statistical tools. Findings: Results have revealed variance in profile characteristics of the respondents which did not manifest any significant relationship with cognitive empathy and leadership performance. Furthermore, it was shown that the middle level educational managers exhibited enhanced and effective functioning skills in the different domains of cognitive empathy and have showcased a high level of leadership in all performance parameters. Generally, cognitive empathy showed a positive significant relationship with leadership performance. Application: Findings imply the need to further strengthen weaker areas of cognitive empathy of middle-level managers as it is proven to impact positive variance on leadership.
\end{abstract}

Keywords: Cognitive Empathy, Leadership Performance, Human Resource Development, Higher Education Leaders, Correlation Design, Social Research

\section{Introduction}

\subsection{Background of the Study}

In recent years, the impacts of emotional intelligence or cognitive empathy to managers' leadership skills and workplace success have gained attention and prompted investigations in scientific communities [1]. Cognitive empathy is believed to be a good predictor or determinant of work performance and leadership ability. It is believed by experts that individuals' over-all intelligence (IQ) only account for not greater than $25 \%$ 
of overall success. With this, the degree to which managers are able to identify and meet the work satisfaction needs of employees and achieve common goals and objectives can be attributable to their cognitive empathy and not only based on their intellectual capacities.

In respect of organizational success, cognitive empathy is considered one of the top 10 important skills in 2020 , along with other skills such as complex problem solving, critical thinking, and people management that will help improve workforce advance to the future in today's age of fourth Industrial Revolution [1]. A Molecular Leadership Model proposed earlier, is identified as a key component that will help managers or leaders cope with the changing complexities of the fourth industrial revolution and will help them assist others from different generations to move forward to achieve success [2].

The aspect of leadership has also been a well-researched concept [3-6] alongside cognitive empathy in the past 20 years emphasizing the importance of the latter in the organizational context. It is argued that inherent to management is leadership and that leadership competence are credited to effective managers [7].

Consequently, competencies of an emotionally intelligent person coincides attributes of effective leadership. As posited that one way to enhance leadership is through the enhancement of cognitive empathy skills [7]. On this note, researchers on leadership have suggested the interplay between transformational leadership and cognitive empathy of managers are essential for the success of an organization [8]. These effective leaders are believed to be skilled at putting their cognitive empathy at the leverage of achieving goals and propelling organizations forward [9].

However, despite considerable attention poured in the area of improving leadership, there is insubstantial data-driven evidence claiming the effectiveness of cognitive empathy in improving leadership [8]. Furthermore, several authors suggested that despite evidences pointing to the significance of emotional intelligence in leadership there is an apparent emotional competence adequacy among leaders in higher education [10].

\subsection{Socio-demographic Characteristics on Cognitive Empathy and Leadership Performance}

Performance of employees is affected by their demographic characteristics [11]. These factors include personal information regarding sex, gender, level of education, level of income, marital status, occupation, religion, and the like [11].

Meanwhile, it is pointed out that commitment to work in an organization is influenced by one's demographic characteristics [12]. These also include personal characteristics such as family size, race, and ethnicity [13]. Demographic characteristics difference initiate differences in expectations among employees [11].

It is suggested that these characteristics must be considered ensuring their profitability and utility towards employees' performance [12]. It is further recommended that institutionalized considerations should be disregarded when managing employee performance, instead, individual's demographic profiles should be given attention [14]. On this note, the importance of socio-demographic characteristics such as age to organizational management has been exemplified. It is cited that the younger the 
employee is the higher the expectations. But as they grow older enthusiasm and energy goes down and so as performance, this is what necessitates the need to formulate policies for retirement [15].

Meanwhile, it was found out that demographic variables have an impact over cognitive empathy and confirmed that females are more emotionally intelligent than males [16]. It was found that marital status is the best predictor of emotional intelligence [17].

\subsection{Leadership Performance}

Research' findings suggest that leaders and effective leadership are instrumental to a university's success [18-19]. Excellent management or administration is crucial in the sustainability and improvement of institutional performance and quality [20]. In [21] higher education, effective leadership is suggested to foster a culture that will promote effective teaching and learning which is central to academic excellence. It is believed that one factor contributing to effectiveness is leadership traits [22].

However [23], in the context of higher education, oftentimes, an organization structure is filled with some academic personnel who lack the proper skills and experience in formal management. In [24] this regard, researchers asserted that in higher education there is inadequacy in leadership training and that most leadership development is based on personal efforts the leaders.

In [19] line with designing leadership training programs for higher education institutions, leadership traits should be considered in order to address effective leadership. In [19-20] some studies, parameters of effective leadership in higher education have established behaviors for effective leadership in higher education were conceptualized and clusters of practices for effective leadership were developed $[19,10]$.

\subsection{Emotional Intelligence and Its Impact to Leadership Performance}

Studies have shown that there is a positive correlation between cognitive empathy and employees work performance [25]. This may be explained by the impact of one's emotional awareness and management to awareness and management of employees' emotions that can enhance morale in the organization [26].

Cognitive empathy is described as an indicator which delineates exceptional and average performance [27]. Several investigations have suggested that it is a good determinant of work success. In some studies, cognitive empathy has shown predictive power on the performance of employees [28] and was found to correlate moderately with job performance [29].

Evidences have further revealed that cognitive empathy is influential to leaders' performance $[30,23,18]$. One's empathy has specifically been identified as crucial for effective management in higher education [13,18]. In addition, emotional management and social emotional management were identified as other important factors [18,31]. 
However, despite evidences pointing to the linkage between cognitive empathy to leadership in higher education, an apparent inadequacy of cognitive empathy among higher education leaders is observed [10]. As such some researchers have further investigated on specific cognitive empathy trait most influential to leadership [31-32].

From the foregoing constructs, this investigation was prompted in order to better understand the relationship between cognitive empathy and leadership in the context of higher education management. This investigation hopes to feedback on management in order to create a more responsive, dynamic, and relevant management for the benefit of the organization.

\subsection{Objectives of the Study}

This investigation determined the relationship between cognitive empathy and the leadership performance of middle-level managers in the Eastern Samar State University (ESSU). It answered the following specific objectives: (1) To assess the cognitive empathy of the middle level educational managers in ESSU in terms of the following domains: (1.1) Emotional Awareness; (1.2) Emotional Management; (1.3) Social Emotional Awareness; (1.4) Relationship Management; (2) To determine middle level educational managers' leadership performance; (3) To validate if respondents' profile characteristics have significant relationship to their cognitive empathy and leadership performance; and (5) To find out if cognitive empathy has significant relationship to middle level educational managers' leadership performance.

\section{Methodology}

This investigation employed the correlation method of research in order to determine the extent to which cognitive empathy of middle-level managers correlated with their leadership performance. Profile characteristics were also individually correlated with the two (2) active variables.

This study transpired at the ESSU System during academic year 2019-2020 with 59 middle-level managers across campuses involved. These middle-level managers are those who are occupying managerial positions at the middle level, videlicet, Deans, Campus Administrators, and Program Heads and are appointed to these positions during 20182019 up to the current conduct of the investigation. Respondents' profile characteristics (age, academic rank, educational attainment, and years of service) were collected and were individually correlated with other active variables.

In order to obtain the primary data of the investigation, two adopted research questionnaires were utilized. The instruments, “The Quick Emotional Intelligence Selfassessment" adopted from Paul Mohapel (paul.mohapel@shaw.ca) and "Educational Leadership Improvement Tool” by De Franco, J. A. and Golden, N.L. (2003) were administered for a period of three weeks.

Upon collection of $77 \%$ of the instruments from those who have given their consent, data were tabulated and were analyzed using the R commander. 


\section{Results and Discussion}

The discussion only account for 77\% (59 out of 77) of the actual data retrieved from the respondents. Nonetheless, analyses advanced because according to Christensen, Johnson, and Turner (2011) a retrieval rate of more than $75 \%$ is acceptable.

\subsection{Respondents' Profile Characteristics}

Data reveal that on average, around $73 \%$ of the respondents are at their late 30 's and early 40 's, holders of instructor or assistant professor ranks (80\%), have been progressive in earning advanced education (68\% Doctoral Degree holders/with units), and have been serving the institution for more than 2 decades now (51\%). These data are important in understanding other variables for they may play important role in analyzing cognitive empathy and leadership performance as shown in Table 1.

TABLE 1. Frequency and percent distribution of respondents' profile characteristics

\begin{tabular}{lrc}
\hline Profile characteristics & Frequency & Percent \\
\hline Age & & \\
$27-36$ & 83 & 13.6 \\
$37-45$ & 8 & 72.9 \\
$46-55$ & & 13.6 \\
Academic rank & 28 & 47.5 \\
Instructor & 19 & 32.2 \\
Assistant professor & 8 & 13.6 \\
Associate professor & 4 & 6.8 \\
Professor & & \\
Educational attainment & 6 & 10.2 \\
BS with MA units & 13 & 22.0 \\
MA/MS degree & 16 & 27.1 \\
MA/MS degree with doctoral units & 24 & 40.7 \\
Doctoral Degree & & \\
Length of service & 24 & 40.7 \\
1-13 years & 30 & 50.8 \\
14-26 years & 5 & 8.5 \\
27-38 years & & \\
\hline
\end{tabular}

\subsection{Respondents' Cognitive Empathy}

It is evident from the data that on average, most of the respondents have either "enhanced skills" or "effective functioning" in all of the cognitive empathy domains. About $71 \%$ and $56 \%$ of them have effective functioning in terms of emotional awareness and relationship management, respectively. While more than one-half (58\%) have enhanced skills in terms of emotional management and social emotional awareness. These results manifest that managers in ESSU exhibit average to high emotional competence, but despite this positive cognitive empathy skills, majority middle-level management still need to consider improving weaker areas emotional awareness and relationship management by utilizing 
enhanced functioning in emotional management and social emotional awareness as leverage in developing weaker areas as shown in Table 2.

TABLE 2. Frequency and percent distribution of respondents' cognitive empathy by domain

\begin{tabular}{lcc}
\hline & Frequency & Percent \\
\hline Emotional awareness & 3 & \\
Area for enrichment & 42 & 5.1 \\
Effective functioning & 14 & 71.2 \\
Enhanced skills & 1 & 23.7 \\
Emotional management & 24 & 1.7 \\
Area for enrichment & 34 & 40.7 \\
Effective functioning & & 57.6 \\
Enhanced skills & 25 & 42.4 \\
Social emotional awareness & 34 & 57.6 \\
Effective functioning & & \\
Enhanced skills & 2 & 3.4 \\
Relationship management & 33 & 55.9 \\
Area for enrichment & 24 & 40.7 \\
Effective functioning & & \\
Enhanced skills & & \\
\hline
\end{tabular}

Table 3 is a summary of the respondents' cognitive empathy. Expectedly, an almost equal percentage of the respondents have effective functioning and enhanced skills with respect to over-all cognitive empathy. It can be noted, however, that only $41 \%$ have shown enhanced skills. Hence, developing cognitive empathy must be a priority of the administration to address middle-level managers' needs to survive in the fourth industrial revolution.

Being one of the top 10 skills for 2020, strengthening leaders' cognitive empathy is important because it will help managers or leaders cope with the changing complexities of the fourth industrial revolution and will help them assist others from different generations to move forward to achieve success [2].

TABLE 3. Frequency and percent distribution of respondents' over-all cognitive empathy

\begin{tabular}{lcc}
\hline Cognitive empathy & Frequency & Percent \\
\hline Effective functioning & 31 & 52.5 \\
Enhanced skills & 28 & 47.5 \\
Total & $\mathbf{5 9}$ & $\mathbf{1 0 0 . 0}$ \\
\hline
\end{tabular}

\subsection{Respondents' Leadership Performance}

Information reveals that all of the indicators for the different leadership performance parameters have been rated "high" by the respondents $(\mathrm{Mdn}=4)$. It can be implied, that 
the respondents have been performing at the same degree with respect to the different parameters evaluated despite variations in their profile characteristics. This finding is important for it is an indication of positive performance and suggestive of high commitment which is needed to drive learning institutions towards realizing over-all vision and mission as shown in Table 4.

TABLE 4. Summary statistics of respondents' leadership performance by indicators

\begin{tabular}{lll}
\hline Leadership performance indicators & Median & Range \\
\hline Leadership attributes & 4 & 2 \\
Visionary leadership & 4 & 2 \\
Community leadership & 4 & 2 \\
Instructional leadership & 4 & 3 \\
Data-driven Improvement & 4 & 2 \\
Organization to improve students' learning & 4 & 3 \\
Organization to improve self-efficacy & 4 & 2 \\
Cultural competence & 4 & 3 \\
Educational management & 4 & 2 \\
\hline
\end{tabular}

\subsection{Relationship between Respondents Profile Characteristics and Leadership Performance}

As presented, none of the profile characteristics have manifested significant relationship to any of the cognitive empathy domains and leadership performance indicators. Surprisingly, these empirical data indicate that one's awareness and management of emotion, ability to relate to other people, and the competencies in leadership are remotely related to personal characteristics. Implication suggests that cognitive empathy as well as leadership performance may have positive variance in the ESSU system despite age, rank, educational attainment and length of service of the educational managers.

This result contradicts to the findings of Fletchl (2010) suggesting the positive impact of profile characteristics to employees' work commitment. It is also contradictory to the suggested positive impacts of profile characteristics to cognitive empathy [16-17].

However, despite this insignificant relationship of cognitive empathy to leadership performance, this finding has significant bearing on the delegation or staffing functions of the administration. It can be noted that while previous studies revealed that cognitive empathy has been proven to positively impact on leadership performance, this empirical investigation has proven that personal profiles of managers have nothing to do with respect to performance variance. Therefore, regardless of age, rank, level of education, and the length of service, anyone with high cognitive empathy may be designated to middle level managerial positions as shown in Table 5.

\subsection{Relationship between Respondents' Cognitive Empathy and Leadership Performance}

Emotional awareness has shown positively weak relationship with leadership performance $\left(r=.382^{* *}, p=.003\right)$. Meanwhile, emotional management, social emotional awareness, and 
TABLE 5. Correlation between profile characteristics and cognitive empathy and leadership performance

\begin{tabular}{|c|c|c|c|c|c|}
\hline Variable 1 & Variable 2 & $\begin{array}{l}\text { Corr. } \\
\text { coefficient }\end{array}$ & $\begin{array}{c}p \\
\text { value }\end{array}$ & Interpretation & Decision \\
\hline \multirow{6}{*}{ Age } & Emotional awareness & -.112 & .397 & Not significant & Fail to reject null \\
\hline & $\begin{array}{l}\text { Emotional } \\
\text { management }\end{array}$ & -.048 & .720 & Not significant & Fail to reject null \\
\hline & $\begin{array}{l}\text { Social emotional } \\
\text { awareness }\end{array}$ & -.088 & .506 & Not significant & Fail to reject null \\
\hline & $\begin{array}{l}\text { Relationship } \\
\text { management }\end{array}$ & -.090 & .498 & Not significant & Fail to reject null \\
\hline & $\begin{array}{l}\text { Over-all cognitive } \\
\text { empathy }\end{array}$ & -.118 & .375 & Not significant & Fail to reject null \\
\hline & $\begin{array}{l}\text { Leadership } \\
\text { performance }\end{array}$ & -.210 & .111 & Not significant & Fail to reject null \\
\hline \multirow{6}{*}{$\begin{array}{l}\text { Academic } \\
\text { rank }\end{array}$} & Emotional awareness & -.185 & .160 & Not significant & Fail to reject null \\
\hline & $\begin{array}{l}\text { Emotional } \\
\text { management }\end{array}$ & .019 & .888 & Not significant & Fail to reject null \\
\hline & Social Emotional & -.033 & .803 & Not significant & Fail to reject null \\
\hline & $\begin{array}{l}\text { Awareness } \\
\text { Relationship } \\
\text { management }\end{array}$ & .067 & .614 & Not significant & Fail to reject null \\
\hline & $\begin{array}{l}\text { Over-all cognitive } \\
\text { empathy }\end{array}$ & -.054 & .682 & Not significant & Fail to reject null \\
\hline & $\begin{array}{l}\text { Leadership } \\
\text { performance }\end{array}$ & -.008 & .951 & Not significant & Fail to reject null \\
\hline \multirow{6}{*}{$\begin{array}{l}\text { Educational } \\
\text { attainment }\end{array}$} & Emotional awareness & .123 & .352 & Not significant & Fail to reject null \\
\hline & $\begin{array}{l}\text { Emotional } \\
\text { management }\end{array}$ & .135 & .307 & Not significant & Fail to reject null \\
\hline & $\begin{array}{l}\text { Social emotional } \\
\text { awareness }\end{array}$ & .244 & .063 & Not significant & Fail to reject null \\
\hline & $\begin{array}{l}\text { Relationship } \\
\text { management }\end{array}$ & .255 & .051 & Not significant & Fail to reject null \\
\hline & $\begin{array}{l}\text { Over-all cognitive } \\
\text { empathy }\end{array}$ & .219 & .096 & Not significant & Fail to reject null \\
\hline & $\begin{array}{l}\text { Leadership } \\
\text { performance }\end{array}$ & .123 & .352 & Not significant & Fail to reject null \\
\hline \multirow{6}{*}{$\begin{array}{l}\text { Length of } \\
\text { service }\end{array}$} & Emotional awareness & .028 & .832 & Not significant & Fail to reject null \\
\hline & $\begin{array}{l}\text { Emotional } \\
\text { management }\end{array}$ & .023 & .861 & Not significant & Fail to reject null \\
\hline & $\begin{array}{l}\text { Social emotional } \\
\text { awareness }\end{array}$ & .128 & .333 & Not significant & Fail to reject null \\
\hline & $\begin{array}{l}\text { Relationship } \\
\text { management }\end{array}$ & .078 & .555 & Not significant & Fail to reject null \\
\hline & $\begin{array}{l}\text { Over-all cognitive } \\
\text { empathy }\end{array}$ & .053 & .692 & Not significant & Fail to reject null \\
\hline & $\begin{array}{l}\text { Leadership } \\
\text { performance }\end{array}$ & .218 & .098 & Not significant & Fail to reject null \\
\hline
\end{tabular}


relationship managements have shown positively moderate relationship with respondents' leadership performance $\left(r=.422^{* *}, p=.001 ; r=.489^{* *}, p=.000 ; r=.477^{* *}, p=.000\right)$. As to over-all correlation, a moderately positive relationship is manifested between the two variables $\left(r=.536^{* *}, p=.000\right)$. Based on these findings, there is enough evidence to say that cognitive empathy is significantly related to leadership performance. Thus, rejecting the null hypothesis.

Similarly, it was found that emotional intelligence correlated with job performance [29]. It can therefore be implied that positive variance in leadership performance may be explained by managers' awareness of their own emotions, recognition of other people's emotion, and their ability to foster positive social relationship management within their organizations as shown in Table 6.

TABLE 6. Correlation between cognitive empathy and leadership performance of middle level educational managers

\begin{tabular}{|c|c|c|c|c|c|}
\hline Variable 1 & Variable 2 & $\begin{array}{l}\text { Corr. coef- } \\
\text { ficiCent }\end{array}$ & $p$ value & Interpretation & Decision \\
\hline Emotional awareness & \multirow{5}{*}{$\begin{array}{l}\text { Leadership } \\
\text { performance }\end{array}$} & $.382^{* *}$ & .003 & Significant & Reject null \\
\hline Emotional management & & $.422^{* *}$ & .001 & Significant & Reject null \\
\hline $\begin{array}{l}\text { Social emotional } \\
\text { awareness }\end{array}$ & & $.489^{* *}$ & .000 & Significant & Reject null \\
\hline $\begin{array}{l}\text { Relationship } \\
\text { management }\end{array}$ & & $.477^{* *}$ & .000 & Significant & Reject null \\
\hline $\begin{array}{l}\text { Over-all cognitive } \\
\text { empathy }\end{array}$ & & $.536^{* *}$ & .000 & Significant & Reject null \\
\hline
\end{tabular}

\section{Conclusions and Recommendations}

\subsection{Conclusions}

Based on the findings, the study concludes: (1) In general, there is diversity in profile characteristics among middle level educational managers. Most are at their early middle adulthood stage, have earned advanced education, worked for more than 20 years, and are ranked assistant professor; (2) At an average, respondents have manifested high functioning and enhanced cognitive empathy skills in all domains indicating average to high levels of emotional management and social relationship. This is significant as possession of these skills are important for leaders and organizations to survival in the fourth industrial revolution; (3) Leadership performance is at high levels in all indicators suggesting high work commitment, which is essential in achieving the rigors of higher education mandates; (4) Profile characteristics are not significantly related to cognitive empathy and leadership performance. This provides implications to management delegations and staffing function that will address a dynamic and relevant organizational structure; and (5) Variance in leadership performance is attributable to cognitive empathy as supported by a significant relationship between the two. Hence, management should carefully consider cognitive 
empathy as a management attribute regardless of an individual's profile it desires to survive with the changing complexities of the fourth Industrial Revolution.

\subsection{Recommendation}

The following recommendations are advanced based on the conclusions: 1. Further explore other demographic profiles of middle-level managers to gain holistic view of the diversity of middle level educational managers which may input on understanding differences; (2) Consider strengthening of the skills exhibited with "effective functioning" and utilize "enhanced skills" in furthering other competencies; (3) Design dynamic and responsive strategies that will promote leadership performance to a very high level; (4) Probe on other socio-demographic factors as to their relationship to cognitive empathy and leadership performance so as to support or validate or negate current findings; (5) Establish a stronger relation between cognitive empathy and leadership performance by investigating other levels of management in the system both academic and administrative.

\section{References}

1. World Economic Forum. The future of jobs: employment, skills and workforce strategy for the fourth industrial revolution. 2016; 1-167.

2. Mdluli S, Makhupe O. Defining leadership competencies needed for the fourth industrial revolution: leadership competencies 4.0. Africa Expansion Project. 2017.

3. Barbuto JE, Burbach ME. The emotional intelligence of transformational leaders: a field of elected officers. The Journal Social of Psychology. 2006; 146(1), 51-64.

4. Barling J, Slater F, Kelloway EK. Transformational leadership and emotional intelligence: an exploratory study. Leadership \& Organization. 2000; 21(3), 157-161.

5. Gardner L, Stough C. Examining the relationship between leadership and emotional intelligence in senior level managers. Leadership \& Organization Development Journal. 2002; 23(2), 68-78.

6. Sivanathan N, Fekken GC. Emotional intelligence and transformational leadership. Leadership and Organization Development Journal. 2002; 23, 198-204.

7. Dijk C, Freedman J. Differentiating emotional intelligence in leadership. Journal of Leadership Studies. 2007; 1(2), 8-20.

8. Batool BF. Emotional intelligence and effective leadership. Journal of Business Studies Quarterly. 2013; 4(3), 1-11.

9. Goleman D, Boyatzis R, McKee A. The new leaders-transforming the art of leadership into the science of results. Time-Warner: London. 2002.

10. Herbst $\mathrm{HH}$. The e-word in academic leadership: An investigation into the emotional intelligence of managers in a higher education institution. South African Journal of Higher Education. 2007; 21(1), 85-101.

11. Thakur G. The influence of demographic characteristics on performance of academic employee in Kenyatta University. Proceedings of the thirteenth Asia-Pacific conference on global business, economics, finance and banking. 2017.

12. Fletchl V. Work Life Balance - A comparative study of women in senior management positions in Austria, Denmark and Great Britain. GRIN Verlag: Norderstedt. 2010. 
13. George A. Demographic variables and self-efficacy as factors influencing career commitment of librarians in Federal University Libraries in Nigeria. University of Ibadan: Ibadan. 2010.

14. Birechi WK. Socio-Economic factors affecting employee management in Kenya. Institute of Human Resource Management: Nairobi. 2010.

15. Adio G. Demographic variables and self-efficacy as factors influencing career commitment of librarians in Federal University Libraries in Nigeria. University of Ibadan: Ibadan. 2010.

16. Pooja P, Pranab K. Demographic variables and its effect on emotional intelligence: a study on Indian service sector employees. Annals of Neuroscience. 2016; 23, 18-24.

17. Vanishree M. The relationship between emotional intelligence and demographic variables of information technology professionals. Paripex-Indian Journal of Research. 2014; 3(1), 134-136.

18. Scott G, Coates H, Anderson M. Learning leaders in times of change: academic leadership capabilities for Australian higher education. 2008; 1-173.

19. Bryman A. Effective leadership in higher education: final report. Research and Development Series, Leadership Foundation for Higher Education: London. 2009.

20. Gibbs G, Christopher K, Sergio P. Departmental leadership of teaching in research-intensive environments. Research and Development Series, Leadership Foundation for Higher Education: London. 2009; 1-64.

21. Knight P, Trowler PR. Department-level cultures and the improvement of learning and teaching. Studies in Higher Education. 2000; 25(1), 69-83.

22. Zaccaro SJ, Kemp C, Bader P. Leader traits and attributes. In: The nature of leadership. J. Antonakis, T. Cainciolo, R.J. Sternberg (eds.). California: Sage Publications: Sternberg. 2004; 101-124.

23. Rowley DJ, Sherman H. The special challenges of academic leadership. Management Decision. 2003; 41(10), 1058-1063.

24. Anderson D, Richard J. Ideas of leadership underpinning proposals to the Carrick Institute: a review of proposals from the 'Leadership for Excellence in Teaching and Learning Program'. 2006.

25. Barbuto JE, Burbac M.E. The emotional intelligence of transformational leaders: a field of elected officers. The Journal Social of Psychology. 2006; 146(1), 5164.

26. Cherniss C. Emotional intelligence \& organizational effectiveness. 2001.

27. Sterrett AS. The manager's pocket guide to emotional intelligence. HRD Press: Massachusetts. 2000.

28. Law KS, Wong C, Song LJ. The construct and criterion validity of emotional intelligence and its potential utility for management studies. Journal of Applied Psychology. 2004; 89(3), 483-496.

29. Van Rooy DL, Viswesvaran C. Emotion intelligence: A meta-analytic investigation of predictive validity and nomological net. Journal of Vocational Behavior. 2004; 65, 71-95.

30. Rantz R. Leading urban institutions of higher education in the new millennium. Leadership and Organization Development Journal. 2002; 23(8), 456-466.

31. Ying CY, Ting SK. The relationship between emotional intelligence and effective leadership among academic heads in higher learning educational institutions. Paper presented at the international conference on business and economic research. 2010.

32. Coco CM. Emotional intelligence in higher education: strategic implications for academic leaders. Journal of Higher Education Theory and Practice. 2011; 11(2), 112-117. 